УДК 631.467:631.51-044.68:633.16 “321”

(C) 2016

Танчик С. П., доктор сільськогосподарських наук,

Одарченко О. М., аспірант

(науковий керівник - доктор сільськогосподарських наук С. П. Танчик)

Національний університет біоресурсів і природокористування України

\title{
ВПЛИВ «НУЛЬОВОГО» І ТРАДИЦІЙНОГО ОБРОБІТКІВ ІРУНТУ НА КІЛЬКІСТЬ ДОЩОВИХ ЧЕРВ'ЯКІВ У ПОСІВАХ ЯЧМЕНЮ ЯРОГО ПРАВОБЕРЕЖНОГО ЛІСОСТЕПУ УКРАЇНИ
}

\section{Рецензент - доктор сільськогосподарських наук В. Т. Саблук}

\begin{abstract}
Досліджено вплив «нульового» $і$ традииійного обробітків на кількість дощових черв'яків в орному шаpi чорнозему типового у полі ячменю ярого Правобережного Лісостепу Украӥни. Встановлено, щзо відсутність обробітку трунту та накопичення пожнивних решток на його поверхні у варіанті «прямого» висіву позитивно впливали на розвиток популящії дощзових черв 'яків, щзо призводило до збільшення їх кількості у 2,6 разів у порівнянні з полицевим обробітком. Виявлено, щзо за традииійного обробітку від сівби до збирання ячменю ярого відбувалося зменшення дощзових черв'яків більше ніж у 9 разів, у той час як за нульового обробітку даний показник зменшився у 2,2 рази.
\end{abstract}

Ключові слова: трунт, полицевий обробіток, «нульовий» обробіток, дощові черв'яки, ячмінь ярий, шар трунту.

Постановка проблеми. Система основного обробітку грунту є невід'ємною частиною технології вирощування сільськогосподарських культур. Проте для організмів, які використовують грунт в якості основного місця існування, будьяке порушення його верхнього шару призводить до порушення майже всіх компонентів мікроекосистеми середовища, у тому числі і проживання дощових черв'яків. Водночас для збереження $\mathrm{i}$ відновлення родючості грунтів необхідно встановити шляхи вдосконалення існуючих технологій, які сприяли б розвитку корисної грунтової фауни. Для досягнення такої мети необхідно працювати в напрямі оптимізації системи основного обробітку й удобрення, які, насамперед, повинні управляти пожнивними рештками за різних способів обробітку $[2,6]$.

Дощові черв'яки залишаються одними 3 найважливіших організмів, які беруть активну участь у грунтотворчих процесах. Від рівня їх активності залежить властивість грунту покращувати поживний режим, структуру грунту i вміст органічної речовини.

Водночас розвиток популяції дощових черв'яків у грунті залежить від вологості, вмісту органічної речовини, механічного складу, $\mathrm{pH}$ i системи основного обробітку грунту $[4,5]$.

Аналіз останніх досліджень і публікацій, у яких започатковано розв'язання проблеми. В найближчому майбутньому одним 3 основних факторів підвищення врожайності культур стане вміле використання біологічної активності рослин і живих організмів, які впливають на весь комплекс грунтових процесів. Так, за даними В. Т. Гридичина (2013), завдяки дощовим черв'якам на удобрених лише соломою грунтах урожайність ячменю може збільшуватись майже у 2 рази. Застосовуючи технологію «прямого» посіву, кількість дощових черв'яків збільшується ледь не у 40 разів порівняно із застосуванням постійного полицевого обробітку. Саме дощові черв'яки забезпечують кращу інфільтрацію опадів у нижні шари грунту. Крім того, дощові черв'яки здатні переробляти за добу до 5 ц органічних решток на кожному гектарі і перетворювати їх у велику кількість поживних речовин, забезпечуючи формування гумусу до 5 т/га [1].

За результатами досліджень К. Чана (2001) чисельні зміни у популяції дощових черв'яків істотно залежали від інтенсивності обробітку грунту. Також було відмічено, що залежно від інтенсивності і способу обробітку грунту чисельність дощових черв'яків може зменшуватися у 2-9 разів.

Хоча розмір популяції дощових черв'яків і перебував під прямим впливом обробітку грунту, однак повідомлялося, що вона може збільшуватися навіть за глибокого полицевого обробітку за умови додаткового надходження органічної речовини.

Автор досліджень зазначив, що за умови мінімізації обробітку грунту роль дощових черв'яків значно зростає через їхню здатність змінювати фізичні властивості грунту та перетворювати поживні речовини у доступні форми [3].

Не зважаючи на те, що за кордоном питання впливу різних систем обробітку грунту на популя- 


\section{СІЛЬСЬКЕ ГОСПОДАРСТВО. РОСЛИННИЦТВО}

цію черв'яків уже активно вивчається протягом останніх 30 років, в Україні даному питанню досі приділяється мало уваги.

Мета досліджень полягала у встановленні впливу традиційного (полицевого) і «нульового» обробітків на популяцію дощових черв'яків у посівах ячменю ярого в умовах Правобережного Лісостепу України.

Матеріали та методика досліджень. Польова частина експерименту проводилася у стаціонарному досліді ВП НУБіП України «Агрономічна дослідна станція» у короткоротаційній сівозміні упродовж 2014-2015 pp.

Схема чергування культур у сівозміні: соя ячмінь ярий - кукурудза на зерно.

Грунтовий покрив дослідних ділянок - чорнозем типовий малогумусний середньосуглинковий. Вміст гумусу - 3,94 \%, pH - 6,8, ємність поглинання - 32,5 мг. екв. на 100 г грунту, кількість загального азоту - 0,3 \%, фосфору - 0,25 \%, калію - 2,5\%.

Схема польового досліду об'єднує два варіанти основного обробітку грунту: «нульовий» і полицевий. Зміст варіантів:

- «нульовий» обробіток - відсутність механічного обробітку (за виключенням прямого посіву), починаючи з 2005 року;

- традиційний обробіток (контроль) - застосування в якості основного обробітку оранки (на глибину 20-22 см під ячмінь ярий), починаючи 3 2005 року.

Визначення кількості дощових черв'яків проводилося шляхом розкопування моноліту розміром $25 \times 25$ см 3 подальшим його розподілом на шари 0-10, 10-20 і 20-30 см.

Облік проводили на початку вегетації ячменю ярого і в період його збирання.

Кількість дощчових черв'яків в $1 \mathrm{~m}^{2}$ за полицевого і «нульового» обробітків црунту в посівах ячменю ярого

\begin{tabular}{|c|c|c|c|c|c|c|}
\hline \multirow[b]{2}{*}{ Обробіток } & \multirow[b]{2}{*}{$\begin{array}{c}\text { Шар } \\
\text { грунту, см }\end{array}$} & \multicolumn{2}{|c|}{2014} & \multicolumn{2}{|c|}{2015} & \multirow{2}{*}{$\begin{array}{c}\text { Середнє } \\
\text { значення за } \\
2 \text { роки }\end{array}$} \\
\hline & & $\begin{array}{c}\text { Під час } \\
\text { сівби }\end{array}$ & $\begin{array}{c}\text { Під час } \\
\text { збирання }\end{array}$ & $\begin{array}{c}\text { Під час } \\
\text { сівби }\end{array}$ & $\begin{array}{c}\text { Під час } \\
\text { збирання }\end{array}$ & \\
\hline \multirow{3}{*}{ No-till } & $0-10$ & 232 & 112 & 208 & 88 & 160 \\
\hline & $10-20$ & 80 & 40 & 72 & 24 & 44 \\
\hline & $20-30$ & 16 & 0 & 8 & 0 & 6 \\
\hline \multirow{3}{*}{ Оранка } & $0-10$ & 96 & 24 & 88 & 8 & 54 \\
\hline & $10-20$ & 56 & 0 & 40 & 0 & 24 \\
\hline & $20-30$ & 8 & 0 & 8 & 0 & 4 \\
\hline \multicolumn{2}{|c|}{$\mathrm{HIP}_{05}$ (обробіток) } & & & & & 35 \\
\hline \multicolumn{2}{|c|}{ HIP $_{05}$ (шар грунту) } & & & & & 43 \\
\hline \multicolumn{2}{|c|}{ НІР 05 (взаємодії) } & & & & & 60 \\
\hline
\end{tabular}

Результати досліджень. Застосування упродовж останніх 11 років технології прямого посіву сприяло створенню сприятливих умов для розвитку популяції дощових черв'яків у верхніх шарах грунту (див. табл.). У середньому за 2 роки досліджень чисельність дощових черв'яків у шарі 0-30 см становила 210 шт./м², що у 2,6 рази перевищувало цей показник за полицевого обробітку грунту.

Однак, проаналізувавши таблицю, можна зробити висновок про динамічність даного показника у часі. Найбільша кількість черв'яків спостерігалася на початку вегетації ячменю ярого за обох систем основного обробітку грунту. За системи No-till спад їх популяції був менш різким порівняно з оранкою. В середньому за 2014-2015 роки за нульового обробітку кількість дощових черв'яків на час збирання культури у шарі 0-30 см становила 132 шт./м², що у 2,3 рази менше порівняно $з$ показником на початку сезону.

За полицевого обробітку відмічено більш різке коливання даного показника, де спостерігалося його зниження у 9 разів. Виходячи з отриманих результатів, можна зробити висновок, що за полицевого обробітку грунту відбувається значна непродуктивна втрата вологи, а пряме сонячне світло призводить до нагрівання його верхнього шару до високих температур, що в сукупності негативно впливає на популяцію дощових черв'яків. Якщо звернути увагу на розподіл дощових черв'яків по шарах грунту, то в обох варіантах спостерігалася подібна закономірність 3 деякими відмінностями. У підсумку за 2 роки за нульового обробітку у шарі 0-10 см знаходилось у межах 76 \% дощових черв'яків від їх загальної кількості, у шарі 10-20 см - 21\% і у 20-30 см $3 \%$, за традиційного обробітку їх розподіл по шарам відповідно становив 66, 29 і 5 \%. 
Отже, за нульового обробітку основна маса черв'яків (76 \%) зосереджується у верхньому (0$10 \mathrm{cm)} \mathrm{шарі} \mathrm{грунту,} \mathrm{де} \mathrm{зосереджена} \mathrm{валова} \mathrm{час-}$ тина пожнивних решток минулорічної культури. У варіанті полицевого обробітку, не зважаючи на те, що пожнивні рештки знаходяться на глибині близько 15-20 см, проте більша частина дощових черв'яків (66\%) також була зосереджена у верхньому шарі, однак їх розподіл менш виражений, ніж за прямого посіву.

Одним із визначальних факторів, який виражає рівень ефективності технології вирощування сільськогосподарських культур є досягнута урожайність. За «нульового» обробітку грунту середній показник урожайності за роки досліджень становив 4,73 т/га, що на 0,36 т вищий порівняно 3 традиційним обробітком, однак дана різниця знаходиться в межах найменшої істотної різниці.

Висновок. Впровадження системи землеробства No-till за вирощування ячменю ярого у Правобережному Лісостепу України забезпечує накопичення пожнивних решток у верхньому шарі грунту i, як наслідок, ефективніше використовується волога, що в свою чергу сприяло істотному збільшенню популяції дощових черв'яків у верхньому шарі грунту $(0-10 \mathrm{~cm})$ порівняно 3 традиційним обробітком.

Перспективами подальших досліджень $є$ впровадження пожнивних посівів у систему No-till, що дасть змогу додатково накопичувати ще більшу кількість рослинних решток, які дадуть змогу стабілізувати кількість та активність дощових черв'яків упродовж вегетаційного періоду.

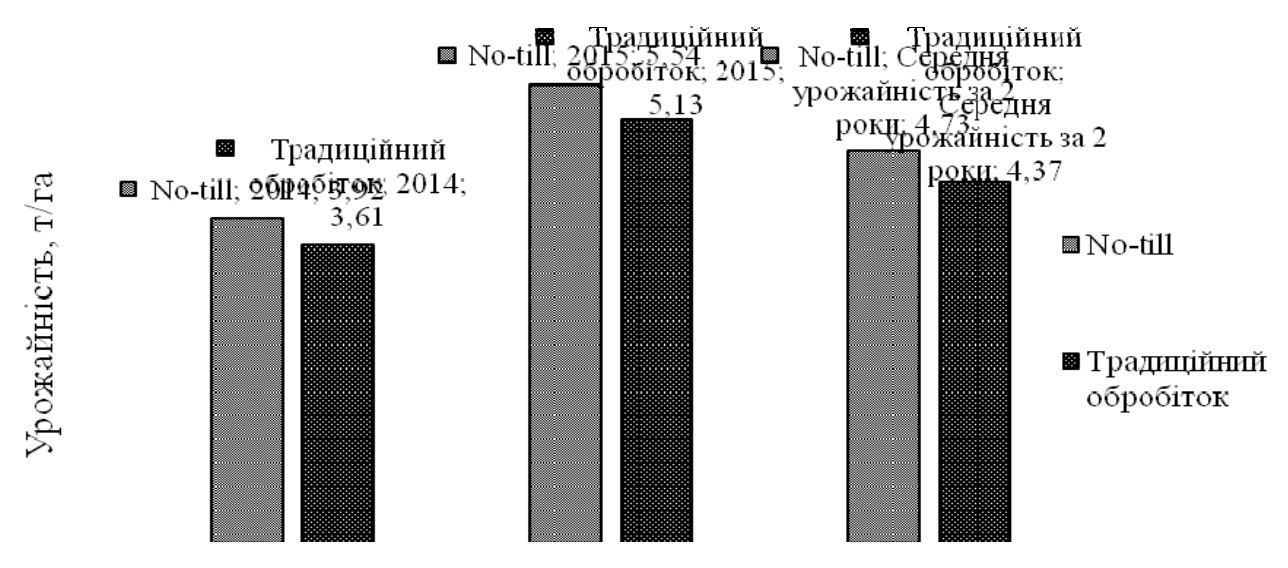

\section{Рис. Урожайність ячменю ярого за різних систем основного обробітку грунту $\left(\mathrm{HIP}_{05}-\mathbf{0 , 4}\right.$ т)}

\section{БІБЛІОГРАФІЯ}

1. Гридчин В. Т. Его величество - червячок / В. Т. Гридчин : матеріали міжнар. семінару [«Практичне природне землеробство: якість продукції, ефективність, перспективи»] (листопад 2013 р.). - Мелітополь, 2013. - С. 144-146.

2. Abundance and distribution of earthworms in relation to landscape factors on the Georgia Piedmont / [Hendrix P., Mueller B., Bruce R. and others] // Soil Biology and Biochemistry. - 1992. №24. - P. 1357-1361.

3. Chan K. Y. An overview of some tillage impacts on earthworm population abundance and diversity: implications for functioning in soils / K. Y. Chan // Soil Tillage Research. - 2001. - №57. -

\section{P. 179-191.}

4. Curry J. P. Intensive cultivation can drastically reduce earth worm populations in arable land / J. P. Curry, D. Byrne, O. Schmidt // European Journal of Soil Biology. - 2002. - №38. - P. 127-130.

5. Edwards C. A. Earthworm Ecology / C. A. Edwards. - Boca Raton : CRC Press, 2004. 456 p. $-\left(2^{\text {nd }}\right.$ ed. $)$.

6. Van Capelle C. Tillage-induced changes in the functional diversity of soil biota - A review with a focus on Germandata / C. Van Capelle, S. Schrader, J. Brunotte // European Journal of Soil Biology. 2012. - №50. - P. 165-181. 